ПЕРЕКЛАДОЗНАВСТВО

UDC 81'255'42:82-1

DOI https://doi.org/10.32838/2663-6069/2019.3-2/06

Gach N. O.

Taras Shevchenko National University of Kyiv

\title{
UKRAINIAN NATIONAL IDENTITY THROUGH THE PRISM OF A BIG CITY VITALITY: CONCEPTUALISING NEW YORK'S CULTURAL LANDSCAPE
}

From the early XXth century Ukrainian poets have transformed New York, a city of dreams, cultures and history, into an integral concept of poetic meanings. Being inspired by its urban vitality, they have created a whole range of poems on city's architecture, people and aura. Thus, New York itself turned into a text valuable for its cultural expression, as the poets talk about such features of the city as subway, bridges, skyscrapers, advertisements, and refer to many place names (Brooklyn, Broadway, Times Square, Wall Street, etc.), which shape city's cultural landscape and become verbal representations of the basic concepts of the Ukrainian mentality. The research shows that the main concepts which constitute the New York City cultural landscape as represented in the Ukrainian poems of the XXthXXIst centuries are HELL / DEATH, MACHINE WORLD, WEALTH / DECORATIONS, POVERTY / IGNORANCE, LAND OF IMMIGRANTS, SOLITUDE. In other words, within the conducted research New York is viewed as a prism for the revelation of the Ukrainian national identity, and historical issues crucial for the Ukrainians in a diachronic perspective (XXth-XXIst centuries).

The comparative analysis of the Ukrainian poems by Mykhail Semenko, Mykola Tarnovsky, Yevhen Malanyuk, Yuri Kosach, Bohdan Boychuk, Yuri Andrukhovych, Oksana Zabuzhko, Serhiy Zhadan and many others, and their translations into English by Ostap Kin, Alexander Motyl, Ali Kinsella, Orest Popovych gives a deep insight into the historical and cultural processes in Ukraine and the USA in the XX-XXIst centuries as being intertwined into one continuum of ideas, beliefs and expectations. The study also examines the ways and strategies the translators use to render the meaning of the original into English. Special attention is paid to the analysis of losses in meaning and form, which happen in the process of literary translation from Ukrainian into English.

Key words: cultural landscape, New York, Ukrainian national identity, concept, poetry translation.

Scientific problem and aims of the study. Recent decades have seen the revitalisation of linguistic interest to the diasporic literature, as it introduces new approaches to think about nations and cultures, challenges the ways in which we understand the world around, and acquaints us with new facets of our national identity. This happens because the poems written in and about foreign and undiscovered places reveal the innermost emotions and feelings of a writer as being opposed to a new surrounding. Therefore, the conducted research is aimed at the cognitive linguistic analysis of the Ukrainian poems written during the $\mathrm{XX}^{\text {th }}-\mathrm{XXX}^{\mathrm{It}}$ centuries about New York, city which sheltered Ukrainians during the times of immigration to the US, and their recent translations into English. The study gives a deep insight into the historical and cultural processes in Ukraine and the USA within the given time span, and outlines modern tendencies in literary translation.
Not all of the poems under analysis were written in New York by immigrant poets (this is mainly the issue for the poems of the first part and the middle of the $\mathrm{XX}^{\text {th }}$ century, times of the Ukrainian immigration to the US). However, as the poems written at the end of the $\mathrm{XX}^{\text {th }}$ century and at the beginning of the $\mathrm{XXI}^{\text {st }}$ centrury were strongly influenced by the previous works due to the close contacts between the immigrant poets and the new generation of Ukrainian writers, the scope of the research was extended on more recent poems in order to get a holistic understanding of the relations of Ukrainians with the American reality.

Latest research analysis. The exploration of the cognitive nature of translation adds to the wide array of studies both on the diasporic literature in Western and non-Western contexts $[1 ; 5 ; 6]$ and new approaches to literary translation $[2 ; 5 ; 7 ; 11]$. As the conducted analysis is based on the study of the 
New York's cultural landscape as represented in the Ukrainian poetry, the works by Carl O. Sauer [10], Vladimir Toporov [3] and Helen Bromhead [4] made a significant contribution to the research, serving as a methodological basis for the city's cultural landscape linguistic analysis.

Discussion. Historically, New York City has always functioned as a harbour - both physically and symbolically - for newcomers. Nowadays the city remains one of the most ethnically diverse urban areas in the world. For example, specific neigh bourhoods throughout the city's five boroughs are home to diverse diasporic groups from Latin America (East Harlem and Bushwick in Brooklyn), Germany (Yorkshire on the Upper East Side), Italy (Manhattan and Brooklyn's Bay Ridge), Poland (Greenpoint in Brooklyn and Ridgewood in Queens), etc.

Staten Island and the East Village in Manhattan house much of the Ukrainian diaspora. For example, the East Village has a lot of cultural features characteristic of the Ukrainian community. One can visit dive bars and restaurants offering the Eastern European cuisine, buy some artworks by Ukrainian artists or books in the Ukrainian bookstores, visit poetry readings and literary discussions at the Literary and Arts Club, or attend exhibitions in the Ukrainian Museum or the Ukrainian Institute of America [9, p. 27-28].

In such a way, the city itself turns into a text, and talks to us through [or with] its streets, squares, waters, islands, gardens, buildings, monuments, people, history, ideas, and can be understood as in its sense a heterogeneneous text which is ascribed a certain general meaning and on a basis of which one could reconstruct a certain system of signs that is realised in a text [3, p. 274-275]. Furthermore, as any text, a city landscape is valuable for its cultural expression. According to Carl O. Sauer, the cultural landscape is the result, where culture is an agent and the natural area - the medium. Thus, under the influence of a given culture, itself changing through time, the landscape undergoes development, passing through phases, and probably reaching ultimately the end of its cycle of development [10, p. 310]. In other words, by studying the city's landscape as depicted in literature, one can learn about a culture and the place of a writer in it.

The poems under analysis give us a broad picture of the New York City cultural landscape, as the poets talk about such features of the city as subway, bridges, skyscrapers, advertisements, and refer to many place names (Brooklyn, Broadway, Times Square, Wall Street, etc.). However, in the context of the analysed poems all these places become verbal representations

of the basic concepts of the Ukrainian mentality, as the poets who belonged to the Ukrainian culture usually compared it with the American one, revealing in this way the differences between the two. Therefore, the New York City text turns out to be pervaded by the memories and sensations of the Ukrainians.

The results of the research have shown that the main concepts which constitute the New York City cultural landscape as represented in the Ukrainian poems of the $\mathrm{XX}^{\text {th }}-\mathrm{XXI}^{\text {st }}$ centuries are the following:

1) HELL / DEATH (typical of the poetry of 1920's - 1980's);

2) MACHINE WORLD (typical of the poetry of 1920's - 2016);

3) WEALTH (physical and mental) / DECORATIONS (typical of the poetry of 1920's 2016);

4) POVERTY (physical and mental)/IGNORANCE (typical of the poetry of 1920's - 1980's);

5) LAND OF IMMIGRANTS (typical of the poetry of 1920's - 2016);

6) SOLITUDE (typical of the poetry of 1980's 2016).

As the Ukrainian nation is a highly religious one, the notions of life and death, heaven and hell are the basic ones in its Christian culture, which is why the concept of HELL / DEATH permeats the Ukrainian poetry of the whole $\mathrm{XX}^{\text {th }}$ century:

Під землею гуркотіння -

Вічний клекіт, шум...

Вогко... Тухло... Темно...

Сум!

Входять люди, а

склепіння

Висне понад ними..

«Собвей»-мов ті катакомби,

станції мов олтарі; всюди виломи і щомби мов казкові упирі!

Пруться люди до

вагонів -

Спішно, вперто... (це життя?)

Мов у пащу лізуть смерті -

Без надії, без пуття... Зяюті злі і чорні пащі Під домами вшир і вглиб...

Не один за це трудящий Марно смертю тут погиб!

Микола Тарновський, 1924
Rumbling down below Eternal roar, scream.. Humid... Rancid... Wretched... Grief! Down the people go, The vaults hanging overhead...

The subway is like the crypts,

The stations are like altars; Everywhere pits and zombies

Like fantastical monsters! The people push their way to the cars Impatient, stubborn... (what life is this?) Like they're climbing into death's jaws

To no avail, and hopeless...

The black and evil jaws gape

Under the houses' depth and breadth

For this, more than one worker

Died a pointless death.

Mykola Tarnovsky, 1924; translated by Abbey

Fenbert 
The translation of Mykola Tarnovsky's poem by Abbey Fenbert, as well as the translations of other Ukrainian poems about New York, is very close to the original in terms of rendering the content of a poem. However, the poetic form and sometimes even poetic meaning is lost in the process of translation. For example, in the original text the author used the transcription of the English word subway-Собвей. This may have been done on purpose to alienate the American reality from the Ukrainian readers, and to make them feel the gap with the far away unknown country full of mysteries and dangers. Obviously, this idea is lost in the translation, as the word subway has no connotative meaning for the English speakers. However, the Ukrainian readers may associate the underground means of transport with hell and sufferings.

The last two lines of the poem also demonstrate the loss of the original meaning. To emphasise the futility of the American life Mykola Tarnovsky uses the word трудящий (worker), which during the Soviet times defined the whole caste of people, who conducted the revolution against the upper class and nobility. Of course, the pointless death of such people highly praised in the Soviet Union would have alienated readers from the US, but in the translation the meaning is lost, as the word worker is a neutral one and has no special connotation in the English language.

Due to the richness of nature of their country Ukrainians have always worshipped it, and belived it to be the source of their health and affluence. That is why the image of New York City as a MACHINE WORLD has highly negative connotation and is opposed to the free beauty of the Ukrainian nature:

Ані вершин, ані низин, Що зрошені в веселих водах, -

Сумне ристалище машин

Та мстива, зраджена природа...

Свген Маланюк, 1949

I от життя веде криву

На злих координатах авеню і стрітів.

В безсоняшних щілинах

Мангаттану,

В каньйоні божевільного Бродвею

Ніколи - синява і сонце

- шум дерев

- і подих простору...

Євген Маланюк, 1952-1953
There are no mountains, there are fields,

There are no frolicsome

waters,

There's but the sad charge of automobiles

And the vengeance of

betrayed nature...

Yevhen Malanyuk, 1949, translated by Alexander Motyl

And so life's ugly curves Are plotted on streets and avenues.

In Manhattan's sunless creases,

In Broadway's canyon craziness

There is no blueness and no sun

- the trees don't rustle

- and space never breathes...

Yevhen Malanyuk, 1952-1953, translated by Alexander

The poems show a clear opposition between the frolicsome nature of Ukraine and the cruel New York City landscape: ugly curves of avenues and streets are opposed to mountains and fileds, blueness of the sky and sun. The lexical units with negative connotation (vengeance of betrayed nature; sunless creases; canyon craziness) create a gloomy image of the city.

Interestingly, Yevhen Malanyuk uses a transcribed version of the English word street (вулиия), although there is the Ukrainian word вулиия, which denotes the same notion. Thus, it is one more example of alienation from the American culture, as the Ukrainian word вулиия also has a deep cultural connotation: it means not only a way in a city, but also 1) people living in the neighboring houses; 2) a place of youth gathering for a party; 3) a party itself (mainly in villages). At the same time the English word street lacks such connotations. Therefore, the deeper connotative meaning is lost in the translation, although the alienation from the US reality is quite obvious in the original text.

The conducted analysis showed that the concept WEALTH / DECORATIONS also has negative connotation, as its representation is closely connected to the idea of spiritual POVERTY AND IGNORANCE:

Чудесний нюйоркський «Таймс-свер»,

Гордість американської ночи!

Від реклям, орнаментів й світел

Сліпнуть очі...

$€ c$, чудесний «Таймссвер»

Гордість американської ночи!

Та в грудях віддих спер... Дихати в нім нема чим.

Убожество духа

страшенне тут;

Й не шукай душевного тут зілля...

Як свойого ти не хоч стратити,

То втікай, друже, скоріш звідсілля!

Касандрин, 1924

Декорації! Пишні окраси! The scenery! Lush Сліпнуть очі - блискуча decorations! краса!..

Так багато «артистів», багато -

Та нема в них живої душі!

Микола Тарновський, 1927
Kasandryn, 1924,

New York's wondrous

Times Square

Pride of the American night!

The eyes go blind From the ads, ornaments and lights...

There it is, wondrous Times Square

Pride of the American night!

And in our chests, stifled air Too stale to breathe.

Terrible poverty of the soul Do not seek spiritual

healing here...

If you do not wish to lose your own

Flee this place quickly, my dear!

The eyes go blind -

beautiful brilliance!..

So many such artists, many

And in not one a living soul!

Mykola Tarnovsky, 1927, translated by Abbey Fenbert 
In the poems mentioned above external beautiful brilliance goes together with the bluff and dead spirit, and is contrasted to the spirituality of the Ukrainian soul. Although the translations of the poems are quite literal, some meanings are still lost. Consider the following line: Так багато «артистів», багато vs. So many such artists, many. The meaning of the word artist in the English translation does not reflect the original idea of the author, whose main intention was to show the pretense and superfical nature of people around (the use of the word «артисти»).

The translations of the analysed poems also lack the poetic form of the original - its rhyme and rhythm. However, as the majority of these poems were translated quite recently, the reason for this may be the prevailing tendency in modern translation to use free verse, sacrificing the form for the preservation of meaning.

The topic of immigration is one of the prevalent in the poetry under analysis. Three waves of the Ukrainian immigration to the US left their deep trace in the history and therefore, culture of the Ukrainians up to these days. That is why the concept $\underline{L A N D}$ OF IMMIGRANTS is marked by grief and nostalgia for the motherland:

I найменша дівчинка в
Чайна-тауні,
і старі баптисти в
холодних церквах
Мангетена
навіть не уявляють, які
зірки падають в наші
комини,
і яке смарагдове
часникове листя
росте не наших
футбольних полях.

футбольних полях.

Це ось океан, без початку і кінця,

заливає берег, на якому

стоять китайські їдальні, і тисяча кашалотів ховається в ньому за піском і мулом, навіки віддляючи мене від країни, яку я любив.

Це ось чорні дерева в холодних снігах, Ніби африканки на білих простирадлах, i на кожному дереві сидять птахи, крикливі птахи еміграції, співучі птахи вигнання.

Сергій Жадан, 2008

By using the metaphor birds of emigration/exile sit on every tree the author clearly describes New York City as a place where different nations and religions coexist. However, Serhiy Zhadan clearly shows a contrast between the city and Ukraine using numerous stylistic devices (stars fell in our chimneys; emerald leaves of garlic $<\ldots>$ vs. black trees in cold snow), which are fully preserved in the translation.

The concept of SOLITUDE is closely connected to the previous one, as immigrants always feel loneliness in a country they moved to being far away from their families, friends, and homes. That is why the idea of solitude also permeats the Ukrainian poetry about New York during the whole $\mathrm{XX}^{\text {th }}$ and $\mathrm{XXI}^{\text {st }}$ centuries:

And the smallest little girl in Chinatown, and the old Baptists in the cold churches of Manhattan don't even imagine how the stars fell into our chimneys, and how emerald leaves of garlic

grow on our soccer pitches.

This is ocean, without beginning or end, flooding the shore where

Chinese buffets stand and a thousand sperm whales hide beneath and and silt

separating me forever from the country

I loved.

Here are black trees in cold snow,

like African women on white blankets, and birds sit on every tree, the vehement birds of emigration, the melodious birds of exile.

Serhiy Zhadan, 2008, translated by Ostap Kin
Hi, не пустеля і намет,

Де ввечері святий

спочинок, -

Ось знов любови дикий мед

I лиш пекучі сни про сина,

I самота - глуха жона,

Що доля повінчала 3 нею,

I дні, що їх перетина

Закурений каньйон

Бродвею.

Євген Маланюк, 1953

No, neither desert, nor tent

Provides nighttime's sacred sleep -,

Once more it's love's wild scent

And dreams of my son

quite sweet,

And the deaf wife of

loneliness

That fate be stowed on me, herman,

And all the days that

crisscross

Broadway's smoke-filled canyon.

Yevhen Malanyuk, 1952-1953,

translated by Alexander Motyl

The translator, Alexander Motyl, tries to preserve the rhythm and rhyme of the original by twisting in some cases the shades of original meaning. Consider the line I лиш пекучі сни про сина vs. And dreams of my son quite sweet. The word пекучий means burning / stinging / painful, which in the translation is rendered by quite sweet. As you can see, the meaning turns out to be quite the opposite. Although the main idea of the poem is to show the unbearable state of solitude of a person in exile, it is lost in the translation.

In the original poem the author uses a very beautiful and powerful for the Ukrainians metaphor: любови дикий мед, which may be translated as wild honey of love. In the Ukrainian culture wild honey has a very deep connotative meaning: something very sweet and what is even more important, healing! The phrase wild scent does not reflect this meaning, so the idea of the original poem is again lost in the translation.

Conclusion. The analysed poems represent the conceptual dualism between the American and 
Ukrainian cultures. The results of the research show that all concepts discussed in the article have a negative connotation due to the fact that the USA, New York in particular, is perceived as a land of immigration. All translations of the Ukrainian poems are done in recent years, which explains the use of free verse aimed at preserving the meaning by sacrificing the poetic form. Nevertheless, the existing translations give readers an opportunity to see the connections between the Ukrainian and American cultures, and the place of Ukrainians within the international community, which undoubtedly is an ultimate goal of the translation process.

\section{References:}

1. Варданян М. Свій - Чужий в українській діаспорній літературі для дітей та юнацтва: національна концептосфера, імагологічні моделі : монографія. Кривий Ріг : Діонат, 2018. 406 с.

2. Коломієць Л. Концептуально-методологічні засади сучасного українського поетичного перекладу. Київ : Видавничо-поліграфічний центр «Київський університет», 2004. 521 с.

3. Топоров В. Петербургский текст русской литературы : Избранные труды. Санкт-Петербург : Искусство - СПб, 2003. 616 с.

4. Bromhead H. Landscape and Culture - Cross-linguistic Perspectives. Amsterdam ; Philadelphia : John Benjamins Publishing Company, 2018. 234 p.

5. Di J. Literary Translation. Quest for Artistic Integrity. London and New York : Routledge, 2003. 115 p.

6. Diasporic Literature and Theory - Where Now? / M. Shackleton et al. Newcastle upon Tyne : Cambridge Scholars Publishing, 2008. 196 p.

7. Hassan B. Literary Translation. Aspects of Pragmatic Meaning. Newcastle upon Tyne : Cambridge Scholars Publishing, 2011. $111 \mathrm{p}$.

8. Lam M. Diasporic literature: The politics of identity and language. Cultural China in Discursive Transformation. Journal of Asian Pacific Communication. 2011. P. 309-318.

9. New York Elegies. Ukrainian Poems on the City / O. Kin et al. Boston : Academic Studies Press, 2019. 280 p.

10. Sauer C. The Morphology of Landscape. Berkeley : University of California Press, 1925.

11. The Translator as Author. Perspectives on Literary Translation : Proceedings of the International Conference / C. Buffagni et al. Berlin : LIT Verlag, 2011. 244 p.

\section{ГаЧ Н. О. УКРАЇНСЬКА НАЦІОНАЛЬНА ІДЕНТИЧНІСТЬ КРІЗЬ ПРИЗМУ ВЕЛИКОГО МІСТА: КОНЦЕПТУАЛІЗАЦІЯ КУЛЬТУРНОГО ЛАНДШАФТУ НЬЮ-ЙОРКА}

Ще з початку двадиятого століття українські поети перетворили Нью-Йорк, місто сподівань, культур й історії, на иілісний кониепт поетичних значень. Надихаючись динамікою та енергетикою міста, вони створили низку поезій про архітектуру, ауру й жителів міста. У такий спосіб НьюЙорк перетворився на текст, иінний для дослідників своєю культурною виразністю. У свойх творах поети описують місто в усіх його деталях, створюючи нові й незабутні образи підземки, хмарочосів, реклами, і використовують водночас численні топоніми (Бруклін, Бродвей, Таймс-Сквер, Уолл-Стріт та ін.), які, у свою чергу, формують культурний ландшафт міста і слугують мовними репрезентаціями базових концептів украӥнською ментальності. Результати дослідження показують, що в украйнській поезії XX-ХХІ століть основними концептами, які визначають культурний ландмафт Нью-Йорка, $\epsilon$ ПЕКЛО / СМЕРТЬ, СВІТ МАШИН, БАГАТСТВО / ДЕКОРАЦЇ̈, БІДНІСТЬ / НЕВІГЛАСТВО, ЗЕМЛЯ IМІГРАНТІВ, САМОТНІСТЬ. Інакше кажучи, у рамках проведеного дослідження Нью-Йорк є призмою розкриття украӥнської національної ідентичності в контексті історичних подій, важливих для української начії в діахронічній перспективі (XX-XXI століття).

Порівняльний аналіз віршів авторства Михайла Семенка, Миколи Тарновського, Свгена Маланюка, Юрія Косача, Богдана Бойчука, Юрія Андруховича, Оксани Забужко, Сергія Жадана й інших поетів, а також їхніх перекладів англійською Остапом Кіном, Олександром Мотилем, Алі Кінселою, Орестом Поповичем дозволяє глибше зрозуміти історичні й культурні процеси в Україні та Сполучених Штатах Америки XX-XXI століть, які переплелись у континуум мрій, сподівань і очікувань українців. У статті також висвітлено перекладацькі способи та стратегії відтворення змісту оригіналу англійською мовою. Особливу увагу зосереджено на аналізі втрат змісту й форми у процесі художнього перекладу з української мови англійською.

Ключові слова: культурний ландшафт, Нью-Йорк, українська національна ідентичність, конщепт, художній переклад. 